\title{
Water quality and sustainability of Merdada Lake, Dieng, Indonesia
}

\author{
Sudarmadji ${ }^{1,2, *}$, Slamet Suprayogi ${ }^{1,2}$, Sri Lestari $^{3}$, and Mukhamad Ngainul Malawani ${ }^{2}$ \\ ${ }^{1}$ Hydrology Study Group, Department of Environmental Geography, Faculty of Geography, Universitas Gadjah Mada, Indonesia \\ ${ }^{2}$ Department of Environmental Geography, Faculty of Geography, Universitas Gadjah Mada, Indonesia \\ ${ }^{3}$ Study Program on Environmental Science, the Graduate School of Universitas Gadjah Mada, Indonesia
}

\begin{abstract}
The volcanic lakes in Dieng Plateau offer some unique phenomena, which interest not only tourists but also scientists. However, as the land use changes, the lakes are now facing environmental degradation especially from agricultural practices. This research aims to study the impact of agricultural practices on the environmental degradation of the lakes especially the water quality and analyze the sustainability of the lakes to support water needs. Merdada Volcanic Lake, one of the lakes in Dieng Plateau was selected as the focus of this research. Method conducted on this research are fields survey to collect the physical parameters temperature and conductivity also chemical parameters like $\mathrm{pH}$, Nitrate, BOD, phosphate, and coliform. A complementary data was acquired using interviews method for defining the sustainability of the lake. Based on observation, water level of the lake is gradually decreased, especially during the dry season. At the same time, the agricultural practices in the surrounding area led to soil erosion, which involved surface runoff that transporting sediments into the lake. This research found that the practices of potato cultivation pumped out the water from Merdada Volcanic Lake and distributed over the plantation area. This practice caused a dramatic decrease in the water surface. Besides that, the agricultural practices had several adverse effects on the volcanic lakes in Dieng Plateau especially eutrophication and decrease of water quality in Merdada Lake where nitrate is over from water quality standard class II. Coliform also has an over expected value, range from 3-11 MPN/100 ml.
\end{abstract}

\section{Introduction}

Research on the remote lake that has a big impact from anthropogenic is now categorized as a hot issue in environmental change research. Most of them revealed that the environmental degradations of the lakes were the results from human activities, some of which were agriculture and tourism. Those phenomena caused the ecosystems on the lake changed due to the environmental degradation in their catchment area [1]. A big degradation of invertebrates found on Lake Chaouhu Basin, China is caused by intense agricultural practices in its catchment area [2]. Agricultural practices also lead some problems to environmental degradation and need obligation to rule good agricultural and environmental conditions, which is protection soil from erosion by maintenance soil organic matters and soil structure [3]. In Indonesia, the trophic status of Sudirman Reservoir and Tondano Lake has been examined and revealed that the water quality deteriorations in both lakes were caused by human activities $[4,5]$. Another study on a small lake in Tolire Lake, Ternate, mentioned that the water quality is inevitably influenced by the volcanic activity [6]. The research on small lakes is also interesting because of the interaction between local community and environmental management, which usually considers the principle of local wisdom. Only view studies conducted in a volcanic lake, beside that also identify the human interaction between local communities and surrounding lake environment.

In Java, there are many volcanic lakes with different characteristic, most of them are maar lake. This study try to examine the role of human interaction on lake water use and its water quality in the selected volcanic lake. The study was conducted in Merdada Volcanic Lake and the surrounding areas, which presumably affect the condition of the lake. Merdada Volcanic Lake is located in Karangtengah Village, Batur District, Banjarnegara District and one of the largest lakes in Dieng Volcanic Complex. Merdada Volcanic Lake formed from stratocone Merdada which ages approximately $0.37 \mathrm{Ma}$ [7]. It has no springs and rivers that supply water into the lake. The water input is mostly from rainwater and only few shares of it is from the seepage in the surrounding areas. Therefore, the water level of the lake descends rapidly during the dry season. However, its current condition is much different from the past. The natural beauty, fertile land, and abundant water resource no longer exist in the lake. Due to the presence of various changes and interventions, Merdada Volcanic Lake is no longer interesting from the perspective of tourism [8]. This lake has a thick mud layer, as a result of high sedimentation. The erosion take place in the surrounding area which sediments transported by runoff into the lake. From those presence conditions, Merdada Volcanic Lake is quite difficult for restoration practice because

*Corresponding author: sudarmadji@ugm.ac.id 
peleolimnological study is important key for the success of lake restoration [9]. But this research tries to evaluate the existing condition as a benchmark for future development.

Water availability is very useful for farming, especially in Merdada Volcanic Lake. One of intensive farming cultivated around in Merdada Volcanic Lake is potato (Solanum tuberosum L.). Merdada water has been exploited for agricultural purposes, i.e., irrigating the potato plantation by pumping method. Beside that, the fertilizer need for potato is very high and susceptible for water quality in lake during rainy season. High runoff always happen during rainy day and transported much nutrient into the lake and expected lead to algae bloom or eutrophication. Trophic status of Merdada Volcanic Lake categorize as hypertrophic, but when measured by amount of chlorophyll status of Merdada Lake categorize as oligotrophic [10]. Other research mention that lake surface water temperature is main factor of algae blooming beside other factors like COD and total nitrogen [11]. However, the catchment area of Merdada Volcanic Lake has a steep slope that can create a higher rate of erosion and support for high runoff rate. The use of fertilizers and pesticides also potentially pollutes the lake water. Therefore, the impact of agricultural activities on the water quality and sustainability of Merdada Volcanic Lake becomes necessary to analyse.

\section{Methods}

The research utilized both primary and secondary data. The primary data was collected from fieldwork, while the secondary data was derived from the previous studies on Merdada Volcanic Lake. The research used several tools and instruments for data collection, including, maps (i.e., the administrative maps of Wonosobo and Banjarnegara District), satellite images, GPS for plotting the location of collected data and samples, a set of questionnaire for in-depth interviews with local leaders, and digital camera for documentation. Primary data collected in field are several sample for water quality analysis. Water samples then analyzed through six different parameters; they are temperature, $\mathrm{pH}$, conductivity, $\mathrm{NO}_{3}, \mathrm{COD}$, and phosphate. The locations of the samples were plotted into the maps based on the GPS reading. The location of the research showed by Figure 1.

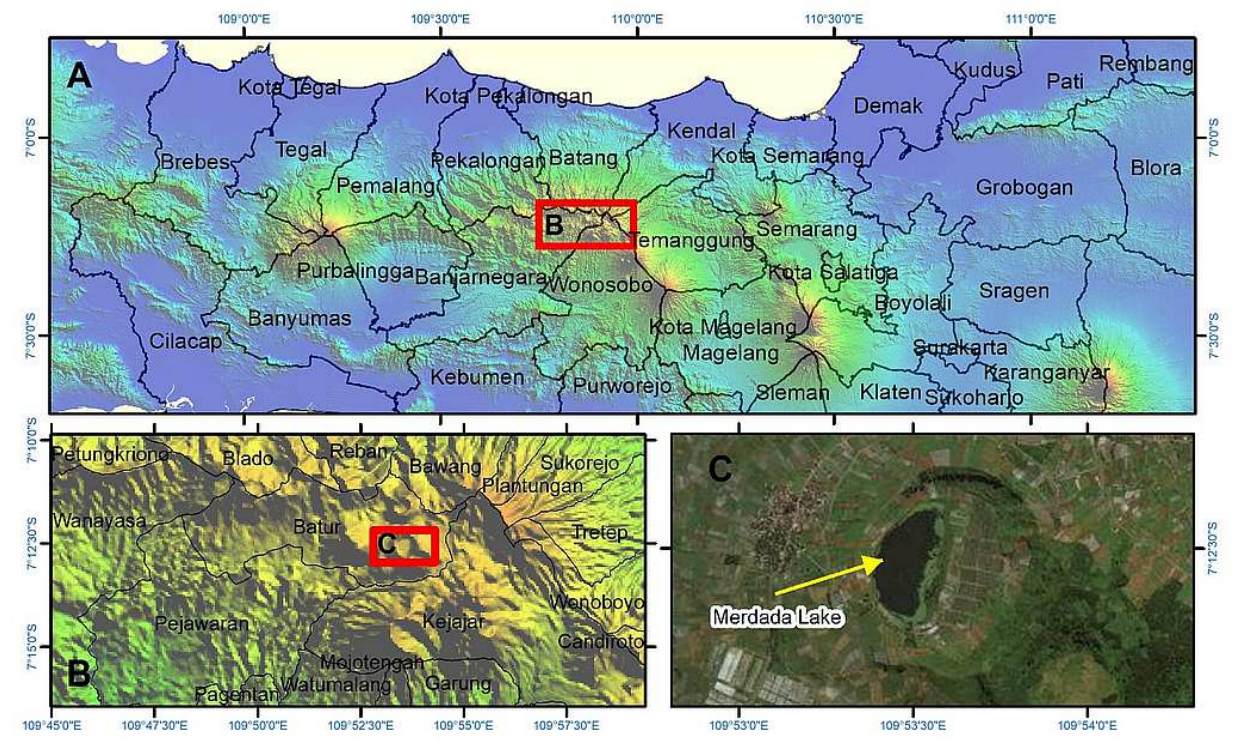

Fig. 1. (A) Location of Merdada Volcanic Lake in Dieng Volcanic Area Jawa Tengah, showing in district border. (B) Located on mountainous area on Dieng Volcanic Complex, showing in sub-district border. (C) Merdada Volcanic Lake has area of 2.5 hectares, over its catchment used as cultivated area.

\section{Results}

The water of Merdada Volcanic Lake is utilized as the source of irrigation water for the surrounding agricultural land, i.e., potato plantation, which gives an enormous impact on the economy of the local communities. The economic improvement is evidenced by the extent of the agricultural land in the area. The water pumping for irrigation is quite excessive. Beside positive impact for economic background, the negative impact of agricultural practices on the environment was clearly shown by the contribution of potato plantation to soil erosion. The surrounding land on Merdada Volcanic Lake was originally used as forest before converted to the agricultural area. The series change of area surrounding Merdada Volcanic Lake showed by Figure 2 . 

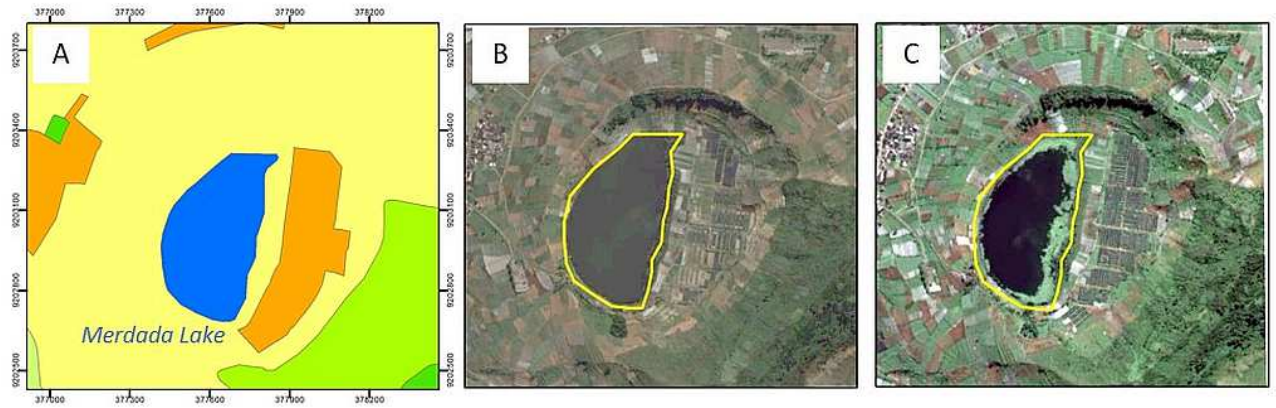

Fig. 2. [A] Merdada lake form RBI Map 1999, area surrounding lake covered by dryland farming. [B] Imagery from Google Earth showed settlement and building on the eastern part of the lake converted into dryland farming. [C] Imagery from 2015 showed that area of the lake shrinking by euthropication processes.

The inland area of the lake that was flattening gradually was utilized as agricultural land. This process would reduce the depth of the lake or, in other words, the lake would become narrower. The erosion and sedimentation processes are clearly observed during the rainy season in which precipitation acts as the agent of erosion. The runoff that flows down from the surrounding areas brings sediments into the lake. The dramatic water decrease on Merdada Volcanic Lake shown in Figure 3 (left) clearly showed how farmer tries hard to use water lake for irrigation even the water almost drain. However, many farmers depend on the availability of water from Merdada Volcanic Lake because of no others water source for irrigating accessible for their land. There were more than 100 water pumps with an estimated pumping duration of 3 hours per suction day.
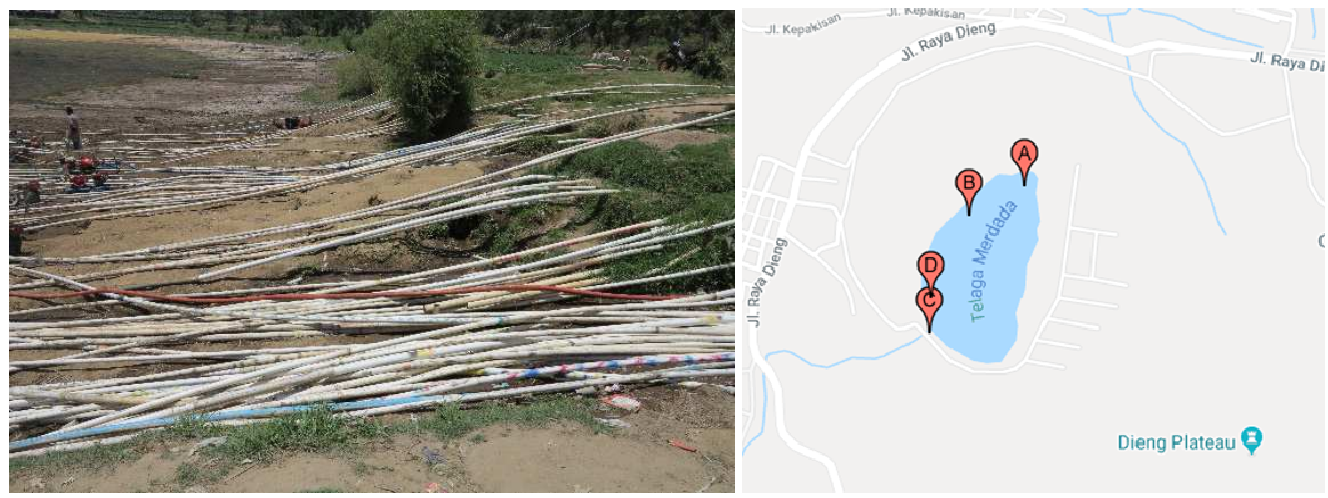

Fig. 3. Water decreases extremely by over pumping activities, the picture was taken in 2015 , a dozens water pump together toke up water for cultivating (left). Samples location for water quality analysis taken from western part of the lake (right).

Several parameters of water quality measured through laboratory analysis, where conducted in the Laboratory of Environment Hidroclimatology, Faculty of Geography, UGM. Fourth sample taken from western part of lake, ranging from north to south. Merdada lake water quality showed that from the four samples value of each parameter has a different result. Nitrate on samples $\mathrm{C}$ has larget value, consist of $2.217 \mathrm{mg} / \mathrm{L}$ while others have values below $2 \mathrm{mg} / \mathrm{L}$. Other parameters with dramatic different are COD. Sample C has lowest COD than other samples. From various parameters, phosphate must be highlighted on sample D because its value has large differences than other samples. Sample D expected rice phosphate $(0.332 \mathrm{~m} / \mathrm{L})$ when other samples has a very small amount of phosphate $(<0.02 \mathrm{mg} / \mathrm{L})$. Its indicated that sample D located near inlet from erosion path moving down from the agricultural slope or supposed to be point of accumulating. Coliform measurement also has different value, ranging form 3-11 MPN $/ 100 \mathrm{~mL}$. Location of sampling sites and its water quality showed in Figure 3 (right) and Table 2. 
Table 2. Water quality of samples has quite different value for each parameter.

\begin{tabular}{|l|c|c|c|c|}
\hline \multicolumn{1}{|c|}{ Parameters } & Sample A & Sample B & Sample C & Sample D \\
\hline Temperature $(\mathrm{C})$ & 27.3 & 27.2 & 25.8 & 27.2 \\
\hline Conductivity $(\mu \mathrm{mhos} / \mathrm{cm})$ & 276.48 & 272.37 & 188.67 & 161.57 \\
\hline $\mathrm{pH}$ & 6.85 & 7.30 & 7.71 & 8.43 \\
\hline $\mathrm{NO}_{3}(\mathrm{mg} / \mathrm{L})$ & 1.328 & 1.105 & 2.127 & 1.744 \\
\hline $\mathrm{COD}(\mathrm{mg} / \mathrm{L})$ & 21.28 & 12.86 & 10.86 & 17.50 \\
\hline Phosphate $(\mathrm{mg} / \mathrm{L})$ & $<0.02$ & $<0.02$ & $<0.02$ & 0.332 \\
\hline
\end{tabular}

\section{Discussion}

Merdada Volcanic Lake with an area of 25 hectares is a potential source for irrigation water. The main water input of the lake is from rainwater, meaning that the water availability of the lake relies solely on the precipitation in the rainy season. The catchment area of the lake is particularly small, which implies a limited amount of water potential. Since Merdada Volcanic Lake receives most of its water from the rain, the water quality is presumed to be similar to the quality of the rainwater. In other words, the lake is expected to contain no excessive substances.

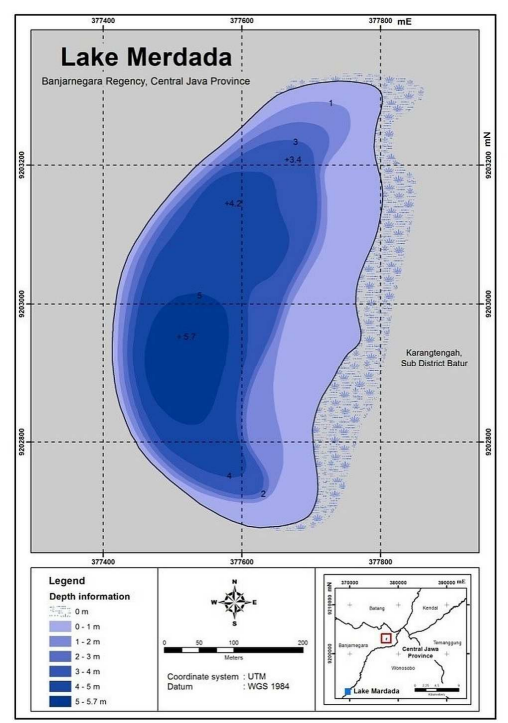

Fig. 4. Merdada Volcanic Lake has an approximately depth 2 meter. The deepest point is $5.7 \mathrm{~m} \mathrm{[12].}$

Merdada Volcanic Lake has no inlet from the river. Thereby, in normal condition, the water is mainly added by rainwater. However, since Merdada Volcanic Lake is extensively used as the source of irrigation water in the surrounding agricultural land, a considerable amount of its water is extracted continuously. Because the excessive use of water, Merdada Volcanic Lake now has an average depth approximately 2 meters and the deepest point is 5.7 meters (Figure 4). By its morphometric measurement, indicated that Merdada Volcanic Lake has an average water volume $0.5 \times 10^{6} \mathrm{~m}^{3}$. Other bathimetric measurement conducted in Merdada Volcanic Lake on different season showed that the deepest point on Merdada lake is 4.2 meters [10]. This is clearly showed that Merdada Volcanic Lake has high fluctuation water level between rainy season and dry season.

The shape of Merdada lake was initially been round (circular), it is indicated from topography showed by DEM data, but the development and human occupation on the west side, including the former mushroom nursery in 1950-1988, changed it into nearly half-round. The erosion and sedimentation in the surrounding area contributed significantly to the changes in the shape of the lake. Morphometric measurement on Merdada lake catchment showed that eastern slope of the lake has a longest slope. The shortest slope in western part of the lake with just below $100 \mathrm{~m}$. Highest different elevation also conducted in eastern slope, ranging about $100 \mathrm{~m}$ above lake water level. Other morphometric measurement showed resembled result with this research [10]. This morphometric characteristic made Merdada Volcanic Lake very vulnerable to lake degradation.

The water scarcity endangered Merdada Volcanic Lake, especially in dry season. Water use for irrigation is main cause the water scarcity of the lake. From the interview with farmers, they used different capacity of water pumping, but it can be estimated that average of water discharge is $40 \mathrm{~L} / \mathrm{min}$ per water pump, similar with $240 \mathrm{~L} / \mathrm{h}$ - other measurement of water pumping taken from a lake near Merdada Volcanic Lake, conducted in Pengilon and Warna Lake [13]. Pengilon and Warna Lake also have water use for irrigation. During potato cultivation, pumping is done for 3 hours every suctioning day. There were 28 time of suctioning during cultivation. In this case, Pengilon and Warna release $12600 \mathrm{~m}^{3}$ for irrigation in every cultivating season. By those scenario, Merdada Lake has more water release for cultivation than Pengilon and Warna Lake. On every season water irrigated from Merdada Lake counting about $14976 \mathrm{~m}^{3}$. In similar scenario, Pengilon and Warna Lake wasted about 360 liters oil from 120 water pump for every cultivating season. But on Merdada Lake oil wasted counting less than them, about 300 liters oil wasted direct or indirectly to Merdada Volcanic Lake water and influenced to its water quality. However, field observation found that the position of the water pumps, which were exactly on the side of the lake, potentially introduced oil spills into the lake and caused contamination like showed in Figure 3 (left). 
Previous research mentions that the water of Merdada Volcanic Lake was suitable for agricultural practices [12]. Those research mentioned that TDS higher on the rainy season than dry season indicated that much of nutrient contained in soil carried by overland flow from cultivated land. Others fact is sediment grain contained on Merdada Volcanic Lake has a similar texture with the topsoil on the cultivated slope, tasted by hand texture observation method. Samples were taken on the dry season (Table 2) also showed that water quality of Merdada Volcanic Lake included adequate low water quality. Compared to Pengilon and Warna lake, Merdada Volcanic Lake is the most affected lake by agricultural impact, indicated by the high amount of nitrate and phosphate. Table 2 showed the comparison between three lakes. In order the effect of agriculture, Warna lake is the most unaffected in term of water quality because volcanic activity is still active on that site [14].

Another water quality measurement on volcanic lake in Azores Archipelagos also showed that physical condition of water quality on volcanic lake is quite different with research area. From 13 volcanic lake from that certain area, $\mathrm{pH}$ is ranging from 4.2 to 9.9 . Besides that, conductivity on those lakes is lower than research area. The lowest conductivity is 6 and the biggest is 159 $\mu \mathrm{mhos} / \mathrm{cm}[15]$. The differences of physical condition from those water quality influenced mostly by the geological setting and human activities on two sites. On Merdada Volcanic Lake, the use of fertilizers for farming triggered the nutrient enrichment in lake and create an environment where aquatic vegetation thrived in the lake. Showed in Figure 3C that new algae was bloom covered water surface compared to Figure $3 \mathrm{~B}$.

Table 2. Comparison water quality between Merdada Lake and others lake

\begin{tabular}{|l|c|c|c|c|c|c|c|}
\hline \multicolumn{1}{|c|}{ Parameters } & Sample A & Sample B & Sample C & Sample D & Average (1) & Average (2) & Average (3) \\
\hline Temperature $\left({ }^{\circ} \mathrm{C}\right)$ & 27.3 & 27.2 & 25.8 & 27.2 & 26.88 & 26.9 & 25.77 \\
\hline $\begin{array}{l}\text { Conductivity } \\
(\mu \mathrm{mhos} / \mathrm{cm})\end{array}$ & 276.48 & 272.37 & 188.67 & 161.57 & 224.77 & 1144 & 184.6 \\
\hline $\mathrm{pH}$ & 6.85 & 7.30 & 7.71 & 8.43 & 7.57 & 3.47 & 8.51 \\
\hline $\mathrm{NO}_{3}(\mathrm{mg} / \mathrm{L})$ & 1.328 & 1.105 & 2.127 & 1.744 & 1.58 & 0.381 & 0.99 \\
\hline $\mathrm{COD}(\mathrm{mg} / \mathrm{L})$ & 21.28 & 12.86 & 10.86 & 17.50 & 15.63 & 2.96 & 9.95 \\
\hline Phosphate $(\mathrm{mg} / \mathrm{L})$ & $<0.02$ & $<0.02$ & $<0.02$ & 0.332 & $<0.02$ & $<0.02$ & 0.153 \\
\hline
\end{tabular}

Average water quality (1) Merdada Lake, (2) Pengilon Lake, (3) Warna Lake; 2 and 3 [14].

The ecosystem of the lake is prone to significant shocks and stresses despite the implementation of some conservation efforts. The conservation is however different from the one that is implemented in a large lake. A large lake requires much-complicated conservation. International Lake Environment Committee (ILEC) Foundation has introduced several guidelines of the conservation efforts [16]. However, some adjustments are required in order to suit the condition in Indonesia. The conservation efforts will not work properly when they focus only on the lake itself because the water in the lake is also influenced by the condition of the catchment area. They have to consider the participation of the local community. Therefore, a comprehensive concept of conservation in Merdada Volcanic Lake becomes necessary in order to sustain the existence of the lake especially focusing on water use regulation on irrigation.

\section{Conclusion}

The potato farming adversely affects the condition of Merdada Lake both directly and indirectly. The sedimentation and siltation of the materials from agricultural land reduce the environmental capacity and, even change the shape of the lake. The water level of Merdada Volcanic Lake will continuously descend due to excessive pumping. The water quality is altered by the unabsorbed fertilizers in agricultural lands, beside that the great number of water pumps can contribute to the decrease in water quality by their oils spilling. Those processes lead Merdada Volcanic Lake to become most vulnerable to environmental degradation compared to others lake in Dieng Area due to agricultural activities. In order to maintain the sustainability of the lake, many efforts need to do especially on the role of water use. Limitation of water pumping is the most important regulation for water conservation in Merdada Lake.

The research was sponsored by The Graduate School of Universitas Gadjah Mada. Authors would like to thank the Vice Director of the Graduate School, Universitas Gadjah Mada for providing many supporting facilities during the research. High appreciation is also addressed to the students of the following study programs: Environmental Science, tourism, and Disaster Management, for their assistance in data collection and during the research. 


\section{References}

1. Sudarmadji. Proceeding Seminar on Limnology. (Faculty of Biology UGM, 2004)

2. Y. Zhang, L. Cheng, K.E. Tolonen, Y. Hongbin, J. Gao, Z. Zhang, K. Li, and Y. Cai. Science of Total Environment. 627. 57-66 (2018)

3. P. Borrelli, K. Paustian, P. Panagos, A. Jones, B. Schütt, E. Lugato. Land Use Policy. 50. 408-421 (2016)

4. A.S. Piranti. Dissertation. (Universiitas Gadjah Mada, Yogyakarta, 2012)

5. S. Wantasen. 2009. Dissertation. (Sekolah pascasarjana UGM. Yogyakarta, 2009)

6. S. Setiawan, H. Wibowo, A..B. Santosa, S. Nomosatryo, I. Yuniarti. Limnotek. 21. 103-114 (2014)

7. A. Harijoko, R. Uruma, H.E. Wibowo, L.D. Setijadji, A. Imai, K. Yonezu, K.J. Watanabe. J. of Volcanology and Geothermal Research. 310. 209224 (2016)

8. M. Rusiah, N. Satya, A. Wahyudin. PELITA. 1. (2005)

9. H. Bennion, G.L. Simpson, B.J. Goldsmith. Frontiers in Ecology and Evolution. 3 (2015)

10. A. Kusumastuti, L.W. Santosa. Majalah Geografi Indonesia. 24 (2010)

11. K. Yang, Z. Yu Y. Luo, Y. Yang, L. Zhao, X. Zhuo. Science of the Total environment. 624. 859-871 (2018)

12. M. Widyastuti, L. Fadilah, F.A. Rasyadi. Research Report. (Fact. Geography UGM, Yogyakarta, 2014)

13. C.Y. Lastiantoro, P.B. Putra, S.A. Cahyono. Prosiding. 241-254. (Seminar Nasional Geografi UMS, 2017)

14. Sudarmadji, H. Pudjiastuti. E3S Web of Conferences. 31 (ICENIS, 2017)

15. P. Antunes, F.C. Rodrigues. Proceedings of symposium IUGG. 106-114 (2011)

16. ILEC. Integrated lake basin management: an introduction. (Kusatsu, Japan, 2007) 